\title{
Predictive factors for the relapse medication overuse headache. A prospective study
}

\author{
A Sergeev ${ }^{*}$, M Mesherina, G Tabeeva \\ From The European Headache and Migraine Trust International Congress \\ London, UK. 20-23 September 2012
}

\section{Introduction}

The prevalence of medication overuse headache $(\mathrm{MOH})$ in population is 1-2 percent, in headache centers is 6070 percent $[1,2]$. The $\mathrm{MOH}$ relapse during the 1 st year after therapy occurs in 30-45 percent [3].

\section{Objectives}

Prospective study of predictive factors of $\mathrm{MOH}$ relapse after drug withdrawal and prophylactic therapy.

\section{Methods}

Trial was performed in 45 patients with $\mathrm{MOH}$ in age from 18 to 65 years (mean age 55, $\pm 9,9$ years). All patients underwent abuse drug withdrawal and the course of preventive therapy. Prospective analysis of clinical-psychological characteristics at 2, 6 and 12 months was performed.

\section{Results}

Predictors of treatment effectiveness and return to episodic headache after 1 year are initially low intensity of headache, low dose of an analgesic per month $(<30$ dose per month), the absence of drug dependence and of high level of depression. Predictors of $\mathrm{MOH}$ relapse after 1 year are impossibility of simultaneous withdrawal of the abuse drug, prolonged course of disease, early age of debut, combination of comorbid disorders (depression, anxiety, personal and mood disorders), high level of analgesic dependency, analgesics containing barbiturates.

\section{Conclusion}

The hypothesis of heterogeneity of the $\mathrm{MOH}$ was confirmed. The 1st type is $\mathrm{MOH}$ without comorbid psychiatric disorders with high level of effectiveness of preventive therapy. The 2nd type is $\mathrm{MOH}$ with comorbid

Sechenov First Moscow State Medical University, Russian Federation psychiatric disorders (depression, anxiety, personal and mood disorders), drug dependence and low efficiency of preventive therapy. The choice of strategy of preventive therapy should be implemented depending on the type of $\mathrm{MOH}$ and identified predictors of relapse.

\section{Conflict of interest}

The authors declare that they have no conflict of interest related to the publication of this manuscript.

Published: 21 February 2013

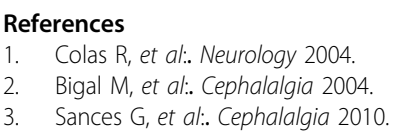

doi:10.1186/1129-2377-14-S1-P173

Cite this article as: Sergeev et al:: Predictive factors for the relapse medication overuse headache. A prospective study. The Journal of Headache and Pain 2013 14(Suppl 1):P173.

Submit your manuscript to a SpringerOpen ${ }^{\circ}$ journal and benefit from:

- Convenient online submission

- Rigorous peer review

- Immediate publication on acceptance

- Open access: articles freely available online

- High visibility within the field

Retaining the copyright to your article

Submit your next manuscript at $>$ springeropen.com
(C) 2013 Sergeev et al; licensee Springer. This is an Open Access article distributed under the terms of the Creative Commons Attribution License (http://creativecommons.org/licenses/by/2.0), which permits unrestricted use, distribution, and reproduction in any medium, provided the original work is properly cited. 